UNIVERSIDADE DE SÃO PAULO

FACULDADE DE ODONTOLOGIA DE RIBEIRÃO PRETO PÓS-GRADUAÇÃO EM PERIODONTIA

Expressão das proteínas citoesqueléticas actina e tubulina em células osteogênicas cultivadas sobre vidro e vitrocerâmica bioativos

Carolina Scanavez Martins

Ribeirão Preto 
Carolina Scanavez Martins

\title{
Expressão das proteínas citoesqueléticas actina e tubulina em células osteogênicas cultivadas sobre vidro e vitrocerâmica bioativos
}

\author{
Dissertação apresentada à Faculdade de \\ Odontologia de Ribeirão Preto - USP, como \\ parte dos requisitos para obtenção do título de \\ Mestre em Periodontia.
}

Orientador: Paulo Tambasco de Oliveira

Ribeirão Preto 
Autorizo a reprodução e divulgação total ou parcial deste trabalho, por qualquer meio convencional ou eletrônico, para fins de estudo e pesquisa, desde que citada a fonte.

FICHA CATALOGRÁFICA

Martins, Carolina Scanavez

Expressão da proteínas citoesqueléticas actina e tubulina em células osteogênicas cultivadas sobre vidro e vitrocerâmica bioativos. Ribeirão Preto, 2012.

51p.: il.; $30 \mathrm{~cm}$

Dissertação de Mestrado, apresentada à Faculdade de Odontologia de Ribeirão Preto da Universidade de São Paulo.

Área de concentração: Periodontia.

Orientador: De Oliveira, Paulo Tambasco

1. Biomateriais. 2. Cultura de células. 3. Citoesqueleto. 4. Vitrocerâmicas.

5. Osteogênese. 6. Materiais bioativos 
Trabalho realizado no Laboratório de Cultura de Células do Departamento de Morfologia, Estomatologia e Fisiologia e no Laboratório de Biologia Molecular do Departamento de Cirurgia e Traumatologia Buco - Maxilo - Facial e Periodontia da Faculdade de Odontologia de Ribeirão Preto da Universidade de São Paulo com bolsa (processo n. 2010/04063-9) e auxílio financeiro (processo n. 2011/01852-5) da Fundação de Amparo à Pesquisa do Estado de São Paulo (FAPESP). 


\section{FOLHA DE APROVAÇÃO}

Carolina Scanavez Martins

Expressão das proteínas citoesqueléticas actina e tubulina em células osteogênicas cultivadas sobre vidro e vitrocerâmica bioativos.

Dissertação apresentada à Faculdade de Odontologia de Ribeirão Preto da Universidade de São Paulo para obtenção do título de Mestre.

Área de Concentração: Periodontia

Aprovado em: / 2012

Banca Examinadora

Prof. Dr.

Instituição: Assinatura:

Prof. Dr.

Instituição: Assinatura:

Prof. Dr. Instituição: Assinatura: 
Dedico este trabalho ao meu orientador PROF. DR. PAULO TAMBASCO DE OLIVEIRA, por sua entrega e competência. Aos meus amados pais JOSÉ ANTÔNIO DE ANDRADE MARTINS E PAULINA AVEZUM SCANAVEZ MARTINS e meu querido noivo RICARDO HENRIQUE CHAGURI, que me apoiaram nessa trajetória, mesmo com dificuldades diversas. Vocês são minha base, o meu bom exemplo, minha coragem e alegria. 
A DEUS, por me manter no caminho e providenciar minha trajetória. AGRADEÇO TODOS OS DIAS DA MINHA VIDA O SEU PLANEJAMENTO PARA O MEU CRESCIMENTO, testando a minha paciência e abrandando meu coração.

À Universidade de São Paulo, representada pelo reitor Prof. Dr. JOÃO GRANDINO RODAS.

À Faculdade de Odontologia de Ribeirão Preto - USP, representada pelo diretor Prof. Dr. VALDEMAR MALLET DA ROCHA BARROS.

Ao Chefe do Departamento de Cirurgia e Traumatologia Buco-Maxilo-Facial e Periodontia, Prof. Dr. CÁSSIO EDVARD SVERZUT.

À Comissão de Pós-graduação da FORP-USP, representada pelo Prof. Dr. ARTHUR BELÉM NOVAES JÚNIOR.

Ao coordenador do Curso de Pós-Graduação em Periodontia, Prof. Dr. ARTHUR BELÉM NOVAES JÚNIOR.

Ao meu orientador, Prof. Dr. PAULO TAMBASCO DE OLIVEIRA, que é uma alma muito nobre, tive muita sorte de conviver e trabalhar com ele e poder usufruir de sua sabedoria e filosofia. MUITO OBRIGADA POR ME ASSISTIR E POR ME ENTENDER.

Aos docentes do curso de Mestrado em Periodontia da Faculdade de Odontologia de Ribeirão Preto - FORP - USP, Prof. Dr. ARTHUR BELÉM NOVAES JÚNIOR, Prof. Dr. MÁRCIO FERNANDO DE MORAES GRISI, Prof. Dr. SÉRGIO LUIS SCOMBATTI DE SOUZA, Prof. Dr. MÁRIO TABA JÚNIOR e Prof. Dra. DANIELA BAZAN PALIOTO, pela convivência e aprendizado transmitidos, desde a especialização.

Especialmente ao Prof. Dr. SÉRGIO LUIS SCOMBATTI DE SOUZA. . Gostaria de agradecê-lo por ter aberto as portas da FORP que tornaram possível cursar o Mestrado em Periodontia.

Aos amigos dos cursos de mestrado, mestrado antigo, doutorado e pós-doutorado, CAROLINA DELMONDES, CAROLINA MANDETTA, IGOR, JANINE, LAURO, LÍVIA, UMBERTO, PATRÍCIA, DANILO, INGRID, LUCIANA, KARINA, DANIA, ADRIANA, 
FLÁVIA, PRISCILA, e ANDRÉA. Todos em algum momento, antes de iniciar o Mestrado, no início, no meio e no fim me ajudaram de alguma forma. Obrigada pela convivência.

À querida amiga ANDRÉA OKUSU, por tornar meus dias mais leves com sua alegria e companheirismo e me receber com tanto carinho em sua casa.

Ao meu querido noivo RICARDO HENRIQUE CHAGURI, que durante todo o mestrado pacientemente tentou sempre diminuir a minha ansiedade, me ajudando em todos os momentos difíceis e desde que chegou em minha vida trouxe mais luz.

Aos colegas do Laboratório de Cultura de Células PATRÍCIA ADACHI, LARISSA SVERZUT, OLÍVIA, WILLIAM, THIAGO E LUCIANA BASTOS, pela ajuda e motivação.

À LARISSA DE CASTRO, LUCAS NOVAES E WILLIAM MARCATTI em especial, pela colaboração com este trabalho.

À aluna de iniciação científica BEATRIZ CARLOS CORREAA, por sua dedicação e ajuda.

À FABÍOLA SINGARETTI DE OLIVEIRA, ROGER RODRIGO FERNANDES, MILA SPRONE TAVARES E SAMUEL SANTORO pela orientação e ajuda indispensáveis na realização dos experimentos no Laboratório de Biologia Molecular e de Cultura de Células, idealizados e criados pelo Prof. Dr. ADALBERTO LUIZ ROSA.

Às secretárias do Departamento de Cirurgia e Traumatologia Buco-Maxilo-Facial e Periodontia da FORP-USP, APARECIDA DULCE NEGRETTI $e$ TATIANA FERNANDES.

Aos funcionários da Faculdade de Odontologia de Ribeirão Preto - USP, especialmente SUELI, por sua amizade, sempre com palavras de carinho.

Aos queridos alunos da Faculdade de Odontologia de Ribeirão Preto - USP, com quem, pelo PAE, tive oportunidade de conviver e orientar, e sempre me trataram com muito carinho.

A todos os PACIENTES, por sua confiança, proporcionando meu crescimento profissional. 
À FUNDAÇÃO DE AMPARO À PESQUISA DO ESTADO DE SÃO PAULO, pela bolsa e auxílio financeiro concedidos à minha pesquisa.

Ao Prof. Dr. SÉRGIO SALVADOR, MARINA E ELIANE, que permitiram utilizar seu laboratório para esterilização de nossas amostras.

À toda a minha família que amo com toda a minha força. 


\section{LISTA DE ABREVIATURAS E SIGLAS}

$\mathrm{CaCO}_{3}$ : carbonato de cálcio

cDNA: ácido desoxirribonucleico complementar

CEUA: comissão de ética no uso de animais

$\mathrm{CO}_{2}$ : gás carbônico

$\mathrm{Ct}$ : ciclo limiar (cicle threshold)

DAPI: 4',6-diamidino-2-phenylindole, dihydrochloride

DEPC: água Milli-Q tratada com dietilpirocarbonato

DNA: ácido desoxirribonucleico

EDTA: ácido etilenodiamino tetra-acético

g: unidade de aceleração, aproximadamente igual a $9,8 \mathrm{~m} / \mathrm{s}^{2}$

GAPDH: D-glyceraldehyde-3-phosphate dehydrogenase

h: hora

HCA: hidroxicarbonatoapatita

$\mathrm{HCl}$ : ácido clorídrico

$\mathrm{kV}$ : kilovolts

M: molar

$\mathrm{m} / \mathrm{v}$ : massa/volume

MEV: microscopia eletrônica de varredura

$\mathrm{mg} / \mathrm{mL}$ : miligrama/mililitro

min: minuto

$\mathrm{mL}:$ mililitro

mm: milímetro 
mM: milimolar

$\mathrm{Na}_{2} \mathrm{CO}_{3}$ : carbonato de sódio

ng: nanograma

nm: nanometro

nM: nanomolar

${ }^{\circ} \mathrm{C}$ : grau Celsius

PB: solução tampão fosfato (Phosphate buffered)

PBS: solução tampão salina de fosfato (Phosphate buffered saline)

Real-time PCR: reação em cadeia de polimerase em tempo real

RNAm: ácido ribonucleico mensageiro

s: segundo

TA: temperatura ambiente

V: volt

$\alpha$-MEM: meio essencial mínimo, modificação $\alpha$

$\mu \mathrm{g}$ : micrograma

$\mu \mathrm{g} / \mathrm{mL}:$ micrograma/mililitro

$\mu \mathrm{L}:$ microlitro

$\mu \mathrm{m}$ : micrometro

$\mu \mathrm{M}$ : micromolar 


\section{RESUMO}

A implantação de materiais vítreos e vitrocerâmicos bioativos representa estratégia terapêutica importante para se promover a formação de matriz extracelular mineralizada em defeitos ósseos críticos. Quando expostos a fluidos biológicos, estes biomateriais sofrem alterações químicas e topográficas de superfície que afetam as interações de células com sua superfície, reduzindo o espraiamento celular e alterando o padrão de marcação de proteínas do citoesqueleto. $\mathrm{O}$ objetivo deste estudo foi avaliar se as alterações no padrão de marcação para as proteínas citoesqueléticas actina e tubulina observadas in vitro em células osteogênicas sobre superfícies do vidro Bioglass ${ }^{\circledR} 45 \mathrm{~S} 5$ e da vitrocerâmica Biosilicato ${ }^{\circledR}$, são decorrentes de redução quantitativa na expressão do RNAm e das proteínas correspondentes. Células osteogênicas foram obtidas a partir da digestão enzimática de calvárias de ratos Wistar recémnascidos e plaqueadas sobre superfícies de Bioglass ${ }^{\circledR} 45 \mathrm{~S} 5$, Biosilicato ${ }^{\circledR}$ e borosilicato (controle bioinerte) para a avaliação dos seguintes parâmetros: 1) detecção de actina e tubulina por microscopia de fluorescência; 2) expressão de RNAm para actina e tubulina por reação em cadeia da polimerase em tempo real (Real time PCR); 3) quantificação de actina e tubulina por ensaio imunoenzimático direto (ELISA), e 4) análise da morfologia celular por microscopia eletrônica de varredura (MEV). Aos 3 e 7 dias, células crescidas sobre borosilicato exibiam padrões de marcação para actina e tubulina típicos de células aderidas e espraiadas sobre substratos planos in vitro, enquanto que sobre Bioglass ${ }^{\circledR} 45 \mathrm{~S} 5$ e Biosilicato ${ }^{\circledR}$ as células apresentavam áreas circulares destituídas de marcação para essas proteínas. Nos mesmos períodos, culturas crescidas sobre os materiais bioativos apresentavam alterações significantes da expressão de RNAm para actina e tubulina, embora fossem observadas apenas discretas variações na quantidade das proteínas correspondentes em relação ao borosilicato. Além disso, apenas para culturas crescidas sobre borosilicato observava-se correlação positiva entre RNAm e proteína e correspondência entre as observações por epifluorescência e os dados quantitativos. Aos 3 dias, imagens de MEV revelaram células aderidas e espraiadas sobre os materiais bioativos, parcial ou totalmente recobertas por acúmulos de material de aspecto semelhante ao da topografia do substrato, por vezes impedindo a visualização dos limites celulares. Com base nos resultados obtidos, conclui-se que as superfícies bioativas de Bioglass ${ }^{\circledR} 45 \mathrm{~S} 5$ e Biosilicato ${ }^{\circledR}$ afetam a expressão de RNAm para actina e tubulina, mas não de proteína. Assim, as alterações nos padrões de marcação por fluorescência para essas proteínas devem ser atribuídas, pelo menos em parte, a acúmulos de material sobre as células, possivelmente decorrentes das reações de superfície a que estão submetidos Bioglass ${ }^{\circledR} 45 \mathrm{~S} 5$ e Biosilicato ${ }^{\circledR}$ quando em contato com fluidos biológicos. 


\begin{abstract}
Bioactive glasses and glass-ceramics have been successfully applied in various therapeutic strategies to promote the formation of mineralized matrix in bone defects. The exposure of these materials to biological fluids results in chemical and topographical modifications that may affect the interactions of cells with the biomaterial surface, with potential effects on cytoskeletal protein expression and/or organization and cell spreading. The aim of the present study was to evaluate whether changes in the labelling pattern for the cytoskeletal proteins actin and tubulin in osteogenic cells cultured on bioactive Bioglass ${ }^{\circledR} 45 \mathrm{~S} 5$ and Biosilicate ${ }^{\circledR}$ are due to altered mRNA and protein expression levels. Osteogenic cells were obtained by enzymatic digestion of newborn Wistar rat calvarial bone and plated on Bioglass ${ }^{\circledR} 45 \mathrm{~S} 5$, Biosilicate $^{\circledR}$ and borosilicate (bioinert control) for periods of up to 7 days. The following parameters were assayed: i) qualitative epifluorescence analysis of actin and tubulin distribution; ii) quantitative mRNA expression for actin and tubulin by real time polymerase chain reaction (real time PCR); iii) quantitative actin and tubulin expression by enzymelinked immunoabsorbent assay (ELISA), and iv) qualitative analysis of cell morphology by scanning electron microscopy (SEM). At days 3 and 7, cells grown on borosilicate showed typical actin and tubulin labeling patterns of adherent and spread cells on flat, rigid substrates, whereas those on Bioglass ${ }^{\circledR} 45 \mathrm{~S} 5$ and Biosilicate ${ }^{\circledR}$ showed dark areas devoid of fluorescent signals for the cytoskeletal proteins. At the same time points, cultures grown on the bioactive materials showed significant changes in mRNA expression for actin and tubulin, although only slight differences in the amount of actin and tubulin were detected compared with borosilicate. Moreover, a positive correlation between mRNA and protein expression levels as well as a correspondence between epifluorescence imaging and the quantitative data were only detected for cultures grown on borosilicate. SEM analysis revealed that cells cultured on bioactive surfaces were partly or totally covered with material accumulations, whose characteristics resembled the ones for the substrate topography, and which, in some cases, prevented the visualization of the cell limits. In conclusion, Bioglass ${ }^{\circledR} 45 \mathrm{~S} 5$ and Biosilicate ${ }^{\circledR}$ affect actin and tubulin mRNA levels, but not the corresponding protein expression, in osteogenic cell cultures. Thus, the observed changes in the labeling pattern for these proteins should be attributed, at least in part, to the accumulation of materials on the cell surface, likely due to substrate reactions that take place on Bioglass ${ }^{\circledR} 45 \mathrm{~S} 5$ and Biosilicate ${ }^{\circledR}$ when exposed to the cell culture medium.
\end{abstract}




\section{SUMÁRIO}

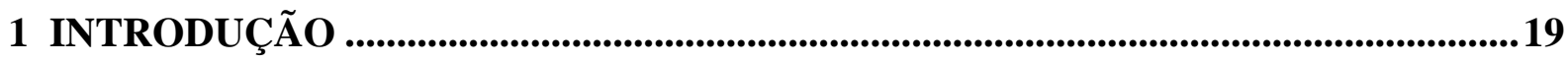

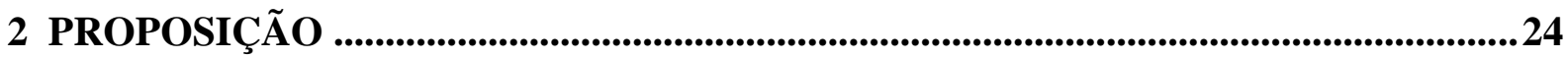

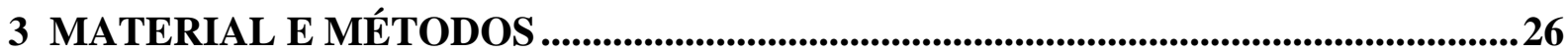

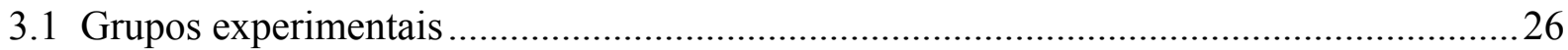

3.2 Isolamento celular e culturas de células osteogênicas..................................................2. 27

3.3 Detecção de actina e tubulina por microscopia de fluorescência ......................................28

3.4 Expressão de RNAm para actina e tubulina por reação em cadeia da polimerase em

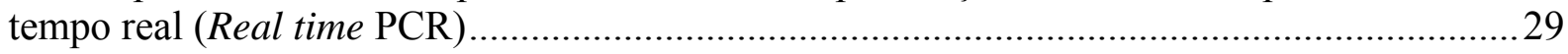

3.5 Quantificação de actina e tubulina por ensaio imunoenzimático direto (ELISA) ............. 31

3.6 Análise da morfologia celular por microscopia eletrônica de varredura (MEV) ..............32

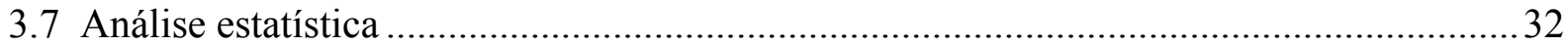

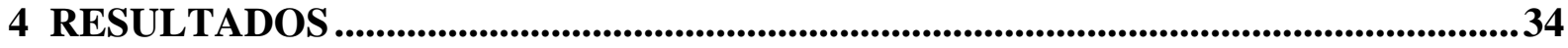

4.1 Detecção de actina e tubulina por microscopia de fluorescência ...................................... 34

4.2 Expressão de RNAm para actina e tubulina por reação em cadeia da polimerase em

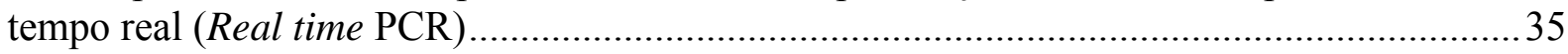

4.3 Quantificação de actina e tubulina por ensaio imunoenzimático direto (ELISA) ............. 36

4.4 Correlação entre a expressão de RNAm e de proteína ..................................................... 38

4.5 Análise da morfologia celular por microscopia eletrônica de varredura (MEV) ..............39

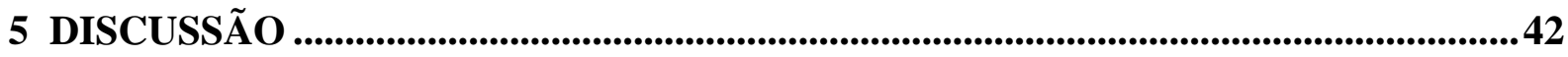

6 CONCLUSÃO

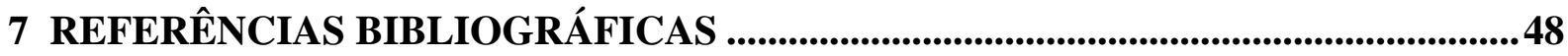




\section{INTRODUÇÃO}

Durante o processo de reparo tecidual nos períodos subseqüentes à implantação de biomateriais, os eventos biológicos na região interfacial estão intimamente relacionados às interações iniciais que células e moléculas da matriz extracelular estabelecem com a superfície do material (KIESWETTER et al., 1996; PULEO; NANCI, 1999; BRUNSKI; PULEO; NANCI, 2000). Aspectos físicos e químicos da superfície dos biomateriais, incluindo composição química, energia de superfície e topografia na micro e nanoescala, podem afetar esses processos interativos e, consequentemente, as características fenotípicas do tecido que será formado (PULEO; NANCI, 1999; DE OLIVEIRA; NANCI, 2004; SCHWARTZ FO et al., 2007; MENDONÇA et al., 2008; VETRONE et al., 2009).

Especial atenção tem sido dada aos efeitos que as diferentes superfícies exercem sobre os eventos celulares de adesão, espraiamento e migração (ANSELME, 2000), os quais estão diretamente ligados à proliferação e diferenciação celular (BETTINGER; LANGER; BORENSTEIN, 2009; VETRONE et al., 2009). Modificações em aspectos topográficos e de plasticidade da matriz extracelular e da superfície de biomateriais podem afetar os fenômenos de agregação de integrinas e de formação de adesões focais, levando a alterações na organização do citoesqueleto (EZZELL et al., 1993; DISCHER; JANMEY; WANG, 2005; BIGGS et al., 2009; BETTINGER; LANGER; BORENSTEIN, 2009; YIM et al., 2010). Tem sido demonstrado que a estruturação do citoesqueleto, incluindo duas de suas principais proteínas, actina e tubulina, constitui-se em fator determinante para a manutenção da morfologia celular, o controle da sinalização citoplasmática e a transcrição gênica (MAMMOTO; INGBER, 2009). Reciprocamente, alterações na morfologia celular afetam o processo dinâmico de formação das adesões focais (CHEN et al., 2003). 
Uma classe de biomateriais utilizados para implantação no tecido ósseo, os vidros bioativos, apresenta uma característica interessante de alterações topográficas e de química de superfície quando em contato com fluidos biológicos, como nos períodos pós-implantação, as quais afetam diferentes aspectos das interações célula-substrato. Na década de 70, Hench publicou os primeiros trabalhos sobre um material vítreo de alta bioatividade, o Bioglass ${ }^{\circledR}$ $45 \mathrm{~S} 5$, pertencente a um sistema quaternário de óxidos $\left(46,1 \% \mathrm{SiO}_{2}, 24,4 \% \mathrm{Na}_{2} \mathrm{O}, 26,9 \% \mathrm{CaO}\right.$ e 2,6\% $\mathrm{P}_{2} \mathrm{O}_{5}$, em mol) ( $\mathrm{HENCH}$ et al., 1971). Diversos estudos comprovaram a bioatividade desse material, demonstrando sua capacidade em promover a proliferação e diferenciação de células da linhagem osteoblástica (DUCHEYNE; QIU, 1999; HATTAR et al., 2005; LOSSDORFER et al., 2004; XYNOS et al., 2000), resultando em aumento da formação óssea tanto in vitro quanto in vivo (DUCHEYNE; QIU, 1999; XYNOS et al., 2000; LOTY et al., 2001).

As alterações topográficas e de química de superfície do Bioglass ${ }^{\circledR} 45 \mathrm{~S} 5$ decorrem de uma mudança gradual em sua superfície em função de alterações no $\mathrm{pH}$, as quais promovem dissolução, precipitação e reações de trocas iônicas (HENCH; POLAK, 2002), culminando com a formação de uma camada de hidroxicarbonatoapatita (HCA), que, por sua vez, irá promover a ligação desse material à matriz extracelular do tecido ósseo (HENCH, 1991). Resumidamente, minutos após a exposição a fluidos corpóreos, ocorre a perda de íons sódio da superfície do material vítreo bioativo pela troca com íons hidrogênio ou hidrônio (Estágio 1). A depleção de sódio causa quebra da rede sílica, bem como das ligações Si-O-Si (Estágio 2). Como resultado, ocorre a formação de grupos silanóis, $\mathrm{Si}(\mathrm{OH})_{4}$, que se repolimerizam em uma camada de sílica-gel, $\mathrm{SiO}_{2}$ (Estágio 3) (LEVY et al., 2007). Em seguida, íons cálcio e fosfato migram e se agregam sobre essa superfície, formando uma camada de fosfato de cálcio amorfo (Estágio 4). A incorporação de íons hidroxila e carbonato, provenientes dos 
líquidos circundantes, induzem à nucleação e cristalização de HCA, muito semelhante à fase mineral da matriz óssea (Estágio 5) (SARAVANAPAVAM et al., 2003).

Apesar dos efeitos benéficos na diferenciação e função de células osteoblásticas, o uso do Bioglass ${ }^{\circledR} 45 \mathrm{~S} 5$ e de outros vidros bioativos para aplicação em engenharia de tecido ósseo tem sido limitado em virtude de suas propriedades mecânicas deficientes (DIEUDONNE et al., 2002). Assim, grupos de pesquisa vêm buscando, nos últimos anos, desenvolver materiais vitrocerâmicos de alta bioatividade, com propriedades mecânicas mais adequadas ao desenvolvimento de arcabouços (scaffolds) (CHEN; THOMPSON; BOCCACCINI, 2006; MOURA et al., 2007; CHEN et al., 2008). Nesse contexto, o Laboratório de Materiais Vítreos da Universidade Federal de São Carlos (LaMaV-UFSCar) desenvolveu uma vitrocerâmica 100\% cristalina $\left(\right.$ Biosilicato $^{\circledR}$, patente WO2004/074199; ZANOTTO et al., 2004) com bioatividade semelhante à do Bioglass ${ }^{\circledR} 45 \mathrm{~S} 5$ quando imersa em fluido corporal simulado K-9 (MOURA et al., 2007). O crescimento de culturas primárias de células osteoblásticas sobre superfície de Biosilicato $^{\circledR}$ e em meio osteogênico resulta em um aumento significativo das áreas de matriz extracelular mineralizada ao final de duas semanas pós-plaqueamento. Outro aspecto interessante, e observado pioneiramente por nosso grupo, foi a redução expressiva da marcação para actina nos primeiros dias de cultura tanto sobre o Biosilicato ${ }^{\circledR}$ como sobre as superfícies controles, de Biosilicato ${ }^{\circledR}$ vítreo e Bioglass ${ }^{\circledR}$ 45S5. A redução da marcação para actina estava associada a alterações na montagem da fibronectina extracelular, e o reaparecimento de fibras de estresse (actin stress fibers) ocorria apenas em áreas de formação de multicamadas celulares.

Em estudo recente, De Castro (2009) confirmou e estendeu essas observações, constatando, por epifluorescência, alterações nos padrões de marcação das proteínas citoesqueléticas actina, vinculina, vimentina e tubulina, da subunidade de integrina $\alpha 5$ e de fibronectina em células osteogênicas aderidas diretamente sobre superfície de Biosilicato ${ }^{\circledR}$. 
Aspectos usuais de marcação para as proteínas avaliadas foram observados apenas nas células que interagiam entre si e não diretamente com o substrato. Análise por microscopia eletrônica de varredura de alta resolução e de força atômica revelou que a superfície de Biosilicato ${ }^{\circledR}$, originalmente plana, exibia, após 3 dias de cultura, células com reduzido espraiamento e topografia do substrato caracterizada por rede de cavidades na submicro e nanoescala, indicando a formação de camada superficial de fosfato de cálcio amorfo (estágio 4 das reações de superfície), como confirmado por FTIR (MOURA et al., 2007). Apesar da originalidade desses resultados qualitativos, não foram realizados até o momento ensaios para confirmar que, efetivamente, as alterações na organização do citoesqueleto estão associadas à redução nos níveis de expressão de RNAm e proteína. 


\section{PROPOSIÇÃO}

O objetivo do presente estudo foi avaliar se as alterações no padrão de marcação para as proteínas citoesqueléticas actina e tubulina observadas in vitro em células osteogênicas sobre as superfícies bioativas do vidro Bioglass ${ }^{\circledR} 45 \mathrm{~S} 5$ e da vitrocerâmica Biosilicato ${ }^{\circledR}$ estão associadas à redução dos níveis de expressão de RNAm e proteína. 


\section{MATERIAL E MÉTODOS}

\subsection{Grupos experimentais}

a) Controle bioinerte, de discos de borosilicato (Pyrex ${ }^{\circledR}$, Corning, EUA), para controle positivo da expressão das proteínas citoesqueléticas actina e tubulina;

b) Bioglass ${ }^{\circledR} 45 \mathrm{~S} 5$, composto por discos do vidro bioativo Bioglass ${ }^{\circledR} 45 \mathrm{~S} 5$, produzido pelo LaMaV-DEMa-UFSCar;

c) Biosilicato $^{\circledR}$, constituído de discos da vitrocerâmica bioativa Biosilicato ${ }^{\circledR}$, produzidos pelo LaMaV-DEMa-UFSCar.

\subsubsection{Preparação dos materiais}

Discos de Biosilicato $^{\circledR}$, de 2,5 $\mathrm{mm}$ de espessura x $12 \mathrm{~mm}$ de diâmetro, foram preparados pelo LaMaV-DEMa-UFSCar. A composição e o protocolo de tratamentos térmicos para obtenção do Biosilicato ${ }^{\circledR}$ estão descritos na patente WO2004/074199 (ZANOTTO et al., 2004). Sílica de alta pureza, carbonato de cálcio, carbonato de sódio e fosfato de sódio foram usados para obter a composição do vidro bioativo Bioglass ${ }^{\circledR} 45 \mathrm{~S} 5$ e Biosilicato $^{\circledR}$ vítreo. Os materiais foram pesados e misturados por $30 \mathrm{~min}$ em garrafa de polietileno. A fusão ocorreu em temperaturas entre 1250 e $1380{ }^{\circ} \mathrm{C}$ por $3 \mathrm{~h}$ em forno elétrico (Rapid Temp 1710 BL, CM Furnaces Inc., Bloomfield, NJ, EUA). As amostras foram colocadas em molde cilíndrico de grafite nas dimensões $10 \mathrm{~mm}$. x $30 \mathrm{~mm}$ e submetidas à fusão a $460{ }^{\circ} \mathrm{C}$ por 5 h. Para obtenção da vitrocerâmica totalmente cristalina (Biosilicato ${ }^{\circledR}$ ), os cilindros contendo Biosilicato ${ }^{\circledR}$ vítreo passaram por ciclo de tratamento térmico para promover sua cristalização. Os primeiros ciclos térmicos foram executados em baixas temperaturas para favorecer a nucleação volumétrica dos cristais. Posteriormente, as amostras 
nucleadas foram submetidas a tratamentos térmicos a uma temperatura superior à de transição do vidro para ocasionar a total cristalização do material. Os cilindros de Biosilicato ${ }^{\circledR}$ foram cortados em discos na espessura de $3 \mathrm{~mm}$ usando lâmina de diamante. Por fim, os discos, de $12 \mathrm{~mm}$ de diâmetro, foram polidos com lixas de carbeto de silício na gramatura 400, imersos em álcool isopropílico e limpos em ultra-som. Em seguida, os discos foram lavados e armazenados em álcool isopropílico, para evitar modificações na superfície causadas pela umidade do ar.

Para os experimentos com cultura de células, os discos de Biosilicato $^{\circledR}$, Bioglass $^{\circledR}$ 45S5 e de vidro bioinerte foram esterilizados em calor seco a $180{ }^{\circ} \mathrm{C}$ em forno de Pasteur por $2 \mathrm{~h}$.

\subsection{Isolamento celular e culturas de células osteogênicas}

As células foram isoladas por digestão enzimática seqüencial, com solução de tripsina e colagenase, de fragmentos de calvárias de ratos Wistar recém-nascidos, com 2-4 dias (BELLOWS et al., 1986; NANCI et al., 1996; DE OLIVEIRA et al., 2003; DE OLIVEIRA; NANCI, 2004; DE OLIVEIRA et al., 2007). Todos os procedimentos com animais estão de acordo com as normas da Comissão de Ética no uso de animais do Campus de Ribeirão da Universidade de São Paulo (CEUA 10.1.1425.53.8, aprovado em 01/12/2010). As células foram plaqueadas sobre os discos de Biosilicato $^{\circledR}$, Bioglass ${ }^{\circledR} 45 \mathrm{~S} 5$ e controle, contidos em placas de 24 poços, na densidade de $2 \times 10^{4}$ células/poço para microscopia de fluorescência e microscopia eletrônica de varredura e $4 \times 10^{4}$ células/poço para Real time PCR e ELISA e foram cultivadas por períodos de 3 e 7 dias em Meio Essencial Mínimo, modificação $\alpha$, com L-glutamina ( $\alpha$-MEM; Invitrogen, Carlsbad, CA, EUA), suplementado com $10 \%$ de soro fetal bovino (Invitrogen), $7 \mathrm{mM}$ de $\beta$-glicerofosfato (Sigma, St Louis, MO, EUA), $50 \mu \mathrm{g} / \mathrm{mL}$ de gentamicina (Invitrogen), $5 \mu \mathrm{g} / \mathrm{L}$ de ácido ascórbico (Sigma) a $37{ }^{\circ} \mathrm{C}$ em uma atmosfera 
úmida contendo $5 \%$ de $\mathrm{CO}_{2}$. O meio de cultura foi trocado a cada 2-3 dias e a progressão da cultura, avaliada por microscopia de fase em culturas crescidas sobre poliestireno. Os resultados apresentados são representativos de duas culturas primárias distintas.

\subsection{Deteç̧ão de actina e tubulina por microscopia de fluorescência}

Em 3 e 7 dias, as células foram fixadas em paraformaldeído a 4\% em tampão fosfato a 0,1 M, pH 7,2 (PB), por 10 min à temperatura ambiente (TA), ou em metanol por 10 min a $20{ }^{\circ} \mathrm{C}$. Em seguida, as células foram processadas para fluorescência direta (DE OLIVEIRA; NANCI, 2004; DE OLIVEIRA et al., 2007; SCHWARTZ FO et al., 2007). A permeabilização foi feita com solução de Triton X-100 a 0,5\% em PB por 10 min, seguida de bloqueio com leite desnatado a 5\% em PB por 30 min. Utilizou-se anticorpo primário monoclonal para $\alpha$-tubulina (1:100, Sigma), seguido de anticorpo secundário conjugados com fluoróforo Alexa Fluor 488 (fluorescência verde; 1:200, Molecular Probes) em mesma solução de faloidina conjugada com Alexa Fluor 594 (fluorescência vermelha; 1:200, Molecular Probes), para visualização do citoesqueleto de actina. Todas as incubações dos anticorpos foram feitas em atmosfera úmida por $60 \mathrm{~min}$ em TA. Entre cada incubação, as amostras foram lavadas três vezes ( 5 min cada) em PB. Antes da montagem para observação microscópica, as amostras foram lavadas rapidamente com água destilada e os núcleos celulares, marcados com DAPI (Molecular Probes) a $300 \mathrm{nM}$ por $5 \mathrm{~min}$. Os discos de Biosilicato $^{\circledR}$, Bioglass ${ }^{\circledR} 45 \mathrm{~S} 5$ e vidro bioinerte, foram montados diretamente em lâminas de vidros, e em seguida, após montagem de lamínula de vidro Fisherbrand $12 \mathrm{~mm}$ (Fisher Scientific) com meio de montagem anti-fade (Vectashield, Vector Labs, EUA) sobre as superfícies contendo células, as amostras foram examinadas utilizando microscópio de fluorescência Leica modelo DMLB (Leica, Bensheim, Alemanha) acoplado a uma câmara 
digital Leica DC 300F. As imagens adquiridas foram processadas com o programa Adobe Photoshop CS5.1.

\subsection{Expressão de RNAm para actina e tubulina por reação em cadeia da polimerase em tempo real (Real time PCR)}

As reações de Real time PCR foram feitas utilizando-se o sistema TaqMan, no aparelho ABI5700 (Applied Biosystems, Foster City, CA, EUA). Após o período de 3 e 7 dias de cultivo celular, foi realizada a extração do RNA total através do kit SV Total RNA Isolation System (Promega, Madison, WI, EUA), de acordo com especificações do fabricante. Em seguida, o RNA total foi quantificado em diferentes comprimentos de onda $(260,280,230$ e $320 \mathrm{~nm}$ ) e sua integridade avaliada através de eletroforese em gel de agarose desnaturante a 1,5\% (m/v). Os tampões para a realização da eletroforese foram preparados com água previamente tratada com dietilpirocarbonato (DEPC, Sigma). Para o preparo da água, foi adicionado $1 \mathrm{~mL}$ de DEPC em $999 \mathrm{~mL}$ de água deionizada, sendo esta mistura incubada à TA por $24 \mathrm{~h}$ e autoclavada por $30 \mathrm{~min}$. O gel foi preparado dissolvendo-se $3 \mathrm{~g}$ de agarose (Gibco, Gran Island, NY, EUA) em 144 mL de água previamente tratada com DEPC. Em seguida, a mistura foi incubada em banho-maria a $65^{\circ} \mathrm{C}$ e, então, foram adicionados $20 \mathrm{~mL}$ de tampão de corrida (10X) (50 mM acetato de sódio, Merck; 5 mM EDTA, Merck; 100 mM de ácido 3[N-morfolino]propanosulfônico, MOPS, Sigma) e $36 \mathrm{~mL}$ de formaldeído a 12,3 M (Merck). A mistura foi despejada em formas adequadas para moldagem do gel. Para o preparo das amostras, foram adicionados para um volume final de $10 \mu \mathrm{L}$ : a) cerca de $2 \mu \mathrm{g}$ de RNA total; b) $2 \mu \mathrm{L}$ de tampão de corrida $(5 \mathrm{X})$; c) $3,5 \mu \mathrm{L}$ de formaldeído a $12,3 \mathrm{M}$; e, d) $10 \mu \mathrm{L}$ de formamida (Merck). Esta mistura foi aquecida a $85{ }^{\circ} \mathrm{C}$ por 10 minutos e, em seguida, submetida a resfriamento a $4{ }^{\circ} \mathrm{C}$. No momento de aplicação das amostras no gel, foram adicionados $2 \mu \mathrm{L}$ de brometo de etídeo (10 mg/mL, Sigma). A eletroforese foi conduzida a 80 
V durante 1 a 3 h, utilizando-se tampão de corrida 1X. Após este período, o gel foi visualizado através de iluminação com luz ultravioleta (UV) a $300 \mathrm{~nm}$. A caracterização de RNA mensageiro (RNAm) de boa qualidade foi verificada pela visualização de duas subunidades ribossômicas características nos eucariotos (18S e 28S). Em seguida, foi confeccionada a fita de cDNA a partir de $1 \mu \mathrm{g}$ de RNA total. Este procedimento foi realizado no termociclador Mastercycle Gradient (Eppendorf, Hamburg, Alemanha) por meio de reação com a enzima transcriptase reversa, utilizando-se o kit SuperScript ${ }^{\mathrm{TM}}$ III First Strand Synthesis Systems para Real-time PCR (Invitrogen). Para a reação de Real time PCR, foram utilizadas sondas TaqMan $^{\circledR}$ (Applied Biosystems) sendo as reações feitas em aparelho ABI5700 (Applied Biosystems). As reações foram realizadas em triplicata com volume final de $15 \mu \mathrm{L}$ e quantidade de cDNA correspondente a $15 \mathrm{ng}$ do RNA inicial. A reação de amplificação foi composta por: a) $50{ }^{\circ} \mathrm{C}$ por $2 \mathrm{~min}$; b) $95{ }^{\circ} \mathrm{C}$ por $10 \mathrm{~min}$ e, c) 40 ciclos a 95 ${ }^{\circ} \mathrm{C}$ por 15 s e $60{ }^{\circ} \mathrm{C}$ por 1 min (desnaturação e extensão).

Os resultados foram analisados com base no valor de $\mathrm{Ct}$ (cicle threshold, ou ciclo limiar), sendo esse o ponto correspondente ao número de ciclos em que a amplificação das amostras atinge um limiar (determinado entre o nível de fluorescência dos controles negativos e a fase de amplificação exponencial das amostras), que permite a análise quantitativa da expressão do fator avaliado. Foi analisada a expressão dos seguintes genes: actina e tubulina.

Como controle endógeno, avaliou-se a expressão do gene GAPDH. A expressão do controle endógeno foi utilizada para a normalização dos níveis de expressão do gene alvo. Uma amostra negativa (água) foi submetida à reação com cada par das sequências dos primers utilizados. O método comparativo de $2^{\text {-ddCt }}$ foi utilizado para comparar a expressão gênica das células osteogênicas cultivadas sobre os diferentes substratos. 


\subsection{Quantificação de actina e tubulina por ensaio imunoenzimático direto (ELISA)}

Ao final de 3 e 7 dias, as proteínas citoesqueléticas actina e tubulina foram quantificadas pela técnica de ELISA a partir de células osteogênicas. As células foram removidas das placas de cultura, sendo adicionados $400 \mu \mathrm{L}$ de solução tampão de lise celular (1x) contendo $20 \mathrm{mM}$ de Tris, $150 \mathrm{mM}$ de NaCl, $1 \mathrm{mM} \mathrm{Na} 2$ EDTA, $1 \mathrm{mM}$ de EGTA, $1 \%$ de Triton, 2,5 $\mathrm{mM}$ de fosfato de sódio, $1 \mathrm{mM}$ de $\beta$-glicerofosfato, $1 \mathrm{mM} \mathrm{Na} \mathrm{V}_{3} \mathrm{VO}, 1 \mu \mathrm{g} / \mathrm{mL}$ de leupeptina (Cell Signaling Thecnology, Danvers, MA, EUA) e $1 \mathrm{mM}$ de inibidor de protease (Sigma, EUA), aguardando um tempo de incubação de 5 min sobre uma superfície refrigerada. Terminado o tempo de incubação, os discos foram raspados para completo lise e remoção das células. Logo após, as células foram sonicadas com três pulsos de dez segundos, potência de 30\% em sonicador (QSonica XL-2000, Newtown, CT, EUA), a $4^{\circ} \mathrm{C}$, para a liberação total das proteínas citoplasmáticas. A suspensão de células lisadas foi, em seguida, centrifugada durante 10 min a $15000 \mathrm{rpm}$, a $4^{\circ} \mathrm{C}$, para separar a fração proteica solúvel do sedimento contendo debris celulares. O sobrenadante foi transferido para um novo tubo e armazenado a $-80^{\circ} \mathrm{C}$ até o dia do experimento.

Para a realização do método ELISA, foi utilizado o Kit PathScan ${ }^{\circledR}$ Elisa (Cell Signaling Technology), para análise das proteínas actina (PathScan ${ }^{\circledR}$ Total $\beta$-Actin Sandwich ELISA Kit) e tubulina (PathScan ${ }^{\circledR}$ Total $\alpha$-Tubulin Sandwich ELISA Kit). As placas foram incubadas com $100 \mu \mathrm{L}$ de uma diluição final de $100 \mu \mathrm{L}$ das amostras e $100 \mu \mathrm{L}$ de diluente da amostra por $2 \mathrm{~h}$ a $37^{\circ} \mathrm{C}$, conforme instruções do fabricante. Em seguida, as placas foram lavadas com $200 \mu \mathrm{L}$ de tampão fosfato contendo detergentes (wash buffer) por 4 vezes. Na última lavagem, a placa foi vertida e seca sobre tiras de papel. Em seguida, a placa foi incubada com $100 \mu \mathrm{L}$ de anticorpo de detecção por $1 \mathrm{~h}$ a $37^{\circ} \mathrm{C}$. Após este período, a placa foi novamente lavada com $200 \mu \mathrm{L}$ de wash buffer por 4 vezes. Foram adicionados $100 \mu \mathrm{L}$ de anticorpo secundário horseradish peroxidase-linked (HRP-linked) e a placa foi incubada por 
30 min a $37^{\circ} \mathrm{C}$. Após este período, a placa foi novamente lavada com $200 \mu \mathrm{L}$ de wash buffer por 4 vezes. Foram adicionados $100 \mu \mathrm{L}$ de substrato TMB (3,3',5,5' tetramethyl benzidine), sendo a placa incubada por 10 min a $37^{\circ} \mathrm{C}$. A reação foi finalizada com a adição de $100 \mu \mathrm{L}$ de ácido sulfúrico a $1 \mathrm{~N}$ (stop solution). Em seguida, foi realizada a leitura da absorbância em leitor de placa ELISA $\mu$ Quant (Biotek Instrument Inc., EUA) no comprimento de onda de 450 nm. Os dados do ELISA foram normalizados pelo conteúdo de proteína total determinado pelo método de Lowry (Lowry et al., 1951), conforme descrito abaixo. Os dados foram expressos como absorbância $450 \mathrm{~nm} /$ proteína total.

\subsection{Análise da morfologia celular por microscopia eletrônica de varredura (MEV)}

A superfície dos discos de material vítreo e controle bioinerte foram também avaliadas por MEV. No $3^{0}$ dia de cultura, células osteogênicas foram fixadas com solução de glutaraldeído a 5\% (Sigma) tamponada com cacodilato de sódio a 0,06 M, pH 7,2 (Sigma) e rotineiramente processadas para MEV (DE OLIVEIRA; NANCI, 2004). As amostras foram avaliadas em microscópio eletrônico de varredura FEI-INSPECT S50, operado a 1,5 kV, no Laboratório de Caracterização Estrutural do Departamento de Engenharia de Materiais da Universidade Federal de São Carlos (LCE-DEMa-UFSCar). As imagens adquiridas foram processadas com o programa Adobe Photoshop CS5.1.

\subsection{Análise estatística}

Os dados quantitativos obtidos foram submetidos aos testes de aderência à curva normal e homogeneidade de variâncias. A distribuição amostral foi constatada não normal, sendo aplicado o teste não paramétrico de Kruskal-Wallis, seguido de pós-teste. O nível de significância foi de 5\%. Os resultados são representativos de experimentos realizados com pelo menos duas culturas distintas. 


\section{RESULTADOS}

\subsection{Detecção de actina e tubulina por microscopia de fluorescência}

Os resultados de localização de actina e tubulina em células osteogênicas crescidas sobre borosilicato, Bioglass ${ }^{\circledR} 45 \mathrm{~S} 5$ e Biosilicato ${ }^{\circledR}$ estão apresentados na Figura 1.

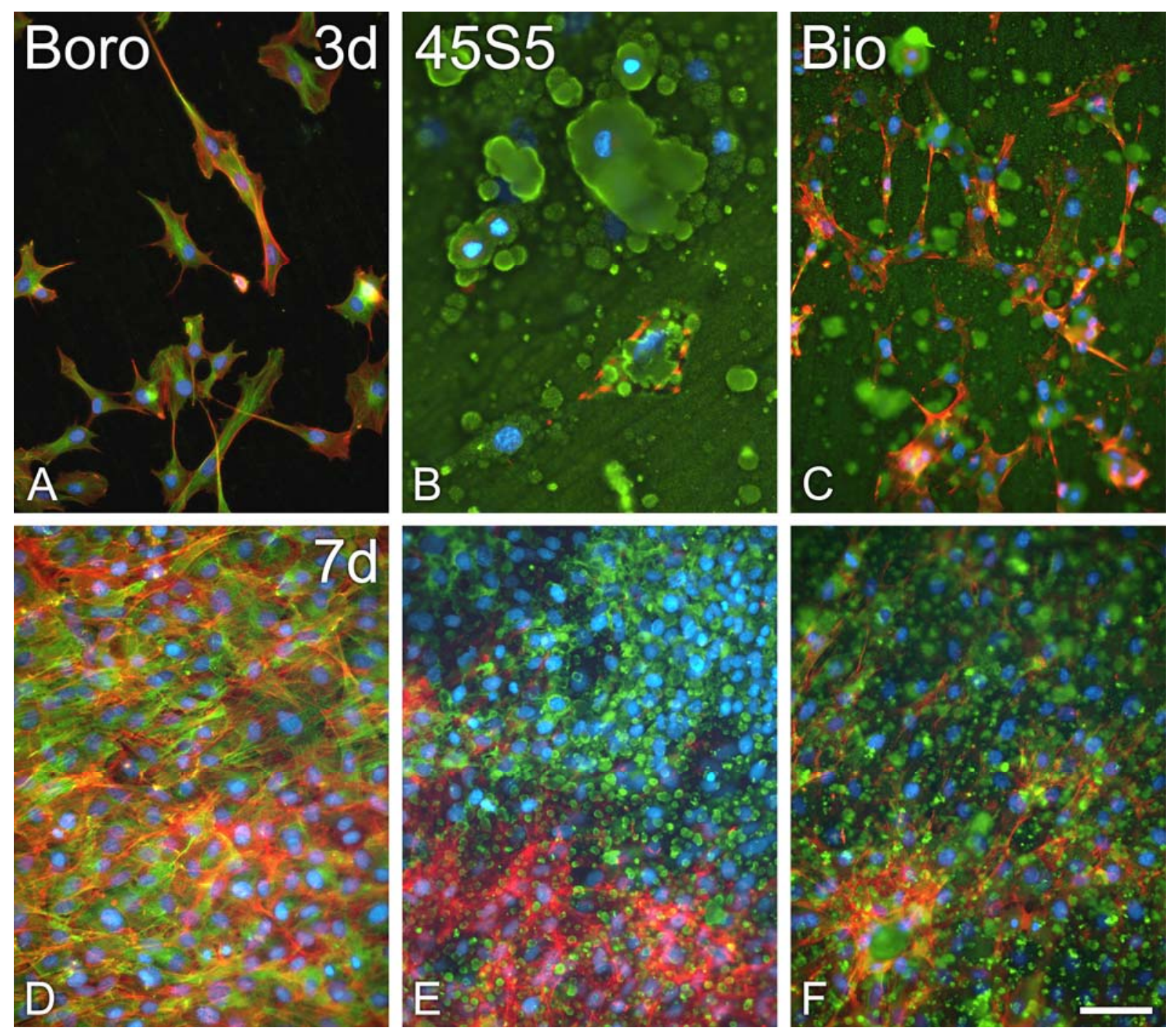

Figura 1. Epifluorescência de células osteogênicas primárias cultivadas sobre borosilicato (Boro, A,D), Bioglass $^{\circledR} 45 \mathrm{~S} 5$ (45S5, B,E) e Biosilicato ${ }^{\circledR}$ (Bio, C,F) por 3 (A-C) e 7 (D-F) dias. Fluorescência vermelha indica actina, fluorescência verde, tubulina e a autofluorescência dos substratos bioativos, e fluorescência azul, núcleos celulares. Notem-se "falhas" na marcação das proteínas citoesqueléticas actina e tubulina em células sobre os materiais bioativos, pelo menos em parte devido a acúmulos esféricos de material sobre as células. Barra de escala $=50 \mu \mathrm{m}$ para A,C-F e $25 \mu \mathrm{m}$ para B. 
Em 3 dias, as células exibiam morfologia poligonal e, qualitativamente, tendência a um menor espraiamento sobre os materiais bioativos, mais facilmente observado para o Biosilicato $^{\circledR}$ (Figura 1, compare C com A). Enquanto que sobre borosilicato a imunomarcação para actina e tubulina mostrava aspectos característicos de células aderidas e espraiadas sobre substratos planos na microescala, distribuindo-se ao redor do núcleo e estendendo-se para os limites do citoplasma, sobre os materiais bioativos sobrepunham-se a esses aspectos "falhas" na marcação por fluorescência, circulares, de limites, por vezes, bem definidos. Nessas culturas, observavam-se, também, acúmulos de material de forma esférica, com autofluorescência verde, depositados tanto sobre células como o substrato (Figura 1, B e C).

Em 7 dias, com a proliferação celular e a confluência das culturas, notava-se a formação de áreas de multicamada celular sobre todos os materiais, cujas células exibiam os aspectos típicos de marcação para actina e tubulina. No entanto, persistiam, predominantemente em áreas de monocamada, pontos de ausência de fluorescência para essas proteínas citoesqueléticas, não observados em células crescidas sobre borosilicato (Figura 1, D-F).

\subsection{Expressão de RNAm para actina e tubulina por reação em cadeia da polimerase em tempo real (Real time PCR)}

Em 3 dias, a expressão de actina era maior para as culturas crescidas sobre Bioglass ${ }^{\circledR}$ 45S5 em comparação àquelas sobre Biosilicato ${ }^{\circledR}$, não havendo diferenças estatisticamente significantes para as demais comparações. Em 7 dias, a expressão de actina era maior para culturas sobre borosilicato quando comparadas àquelas sobre materiais bioativos (Figura 2).

A expressão de tubulina variou entre as culturas crescidas sobre os 3 materiais. Em 3 dias, constatou-se a seguinte ordem crescente: Biosilicato ${ }^{\circledR}<$ borosilicato $<$ Bioglass $^{\circledR} 45 \mathrm{~S} 5$. 
Em 7 dias, a expressão de tubulina era maior para as culturas sobre borosilicato quando comparadas àquelas sobre os materiais bioativos (Figura 3).

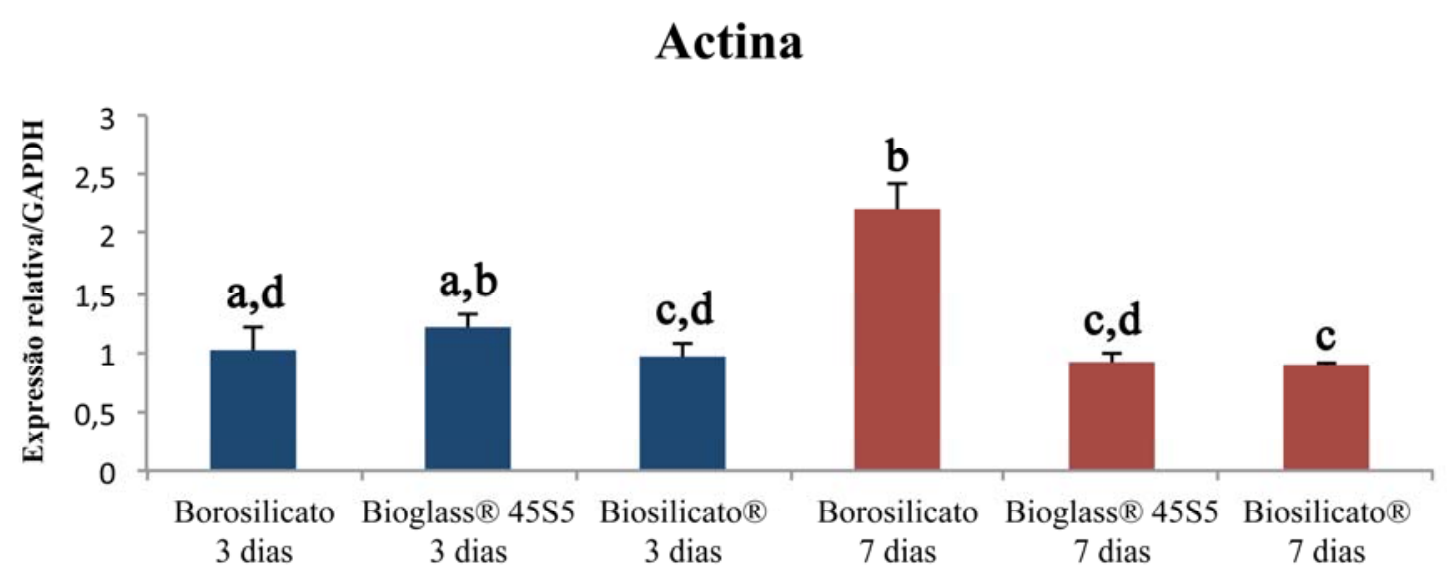

Figura 2. Expressão relativa de RNAm para actina (média \pm desvio padrão) em culturas de células osteogênicas crescidas sobre superfícies de borosilicato, Bioglass ${ }^{\circledR} 45 \mathrm{~S} 5$ e Biosilicato ${ }^{\circledR}$ aos 3 e 7 dias. Barras que compartilham pelo menos uma letra não apresentam diferenças estatisticamente significantes $(p>0,05)$.

\section{Tubulina}

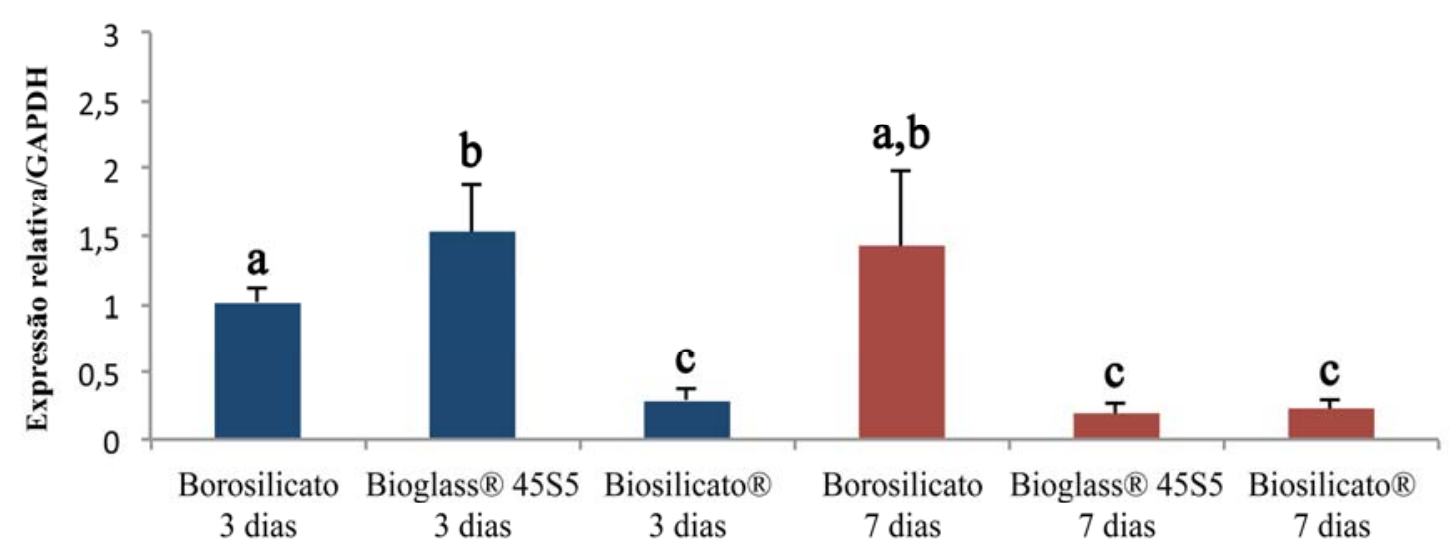

Figura 3. Expressão relativa de RNAm para tubulina (média \pm desvio padrão) em culturas de células osteogênicas crescidas sobre superfícies de borosilicato, Bioglass ${ }^{\circledR} 45 \mathrm{~S} 5$ e Biosilicato ${ }^{\circledR}$ aos 3 e 7 dias. Barras que compartilham uma letra não apresentam diferenças estatisticamente significantes $(p>0,05)$.

\subsection{Quantificação de actina e tubulina por ensaio imunoenzimático direto (ELISA)}

Em 3 dias, a quantidade de actina era maior em culturas crescidas sobre borosilicato se comparada à daquelas sobre Bioglass ${ }^{\circledR} 45 \mathrm{~S} 5$ e Biosilicato ${ }^{\circledR}$; para todos os materiais, os valores de 7 dias eram significativamente maiores do que os de 3 dias (Figura 4). 
Em relação à quantidade de tubulina, não se observaram diferenças entre as culturas sobre os 3 materiais tanto em 3 como em 7 dias, sendo os valores de 7 dias significativamente maiores se comparados aos de 3 dias (Figura 5).

\section{Actina}

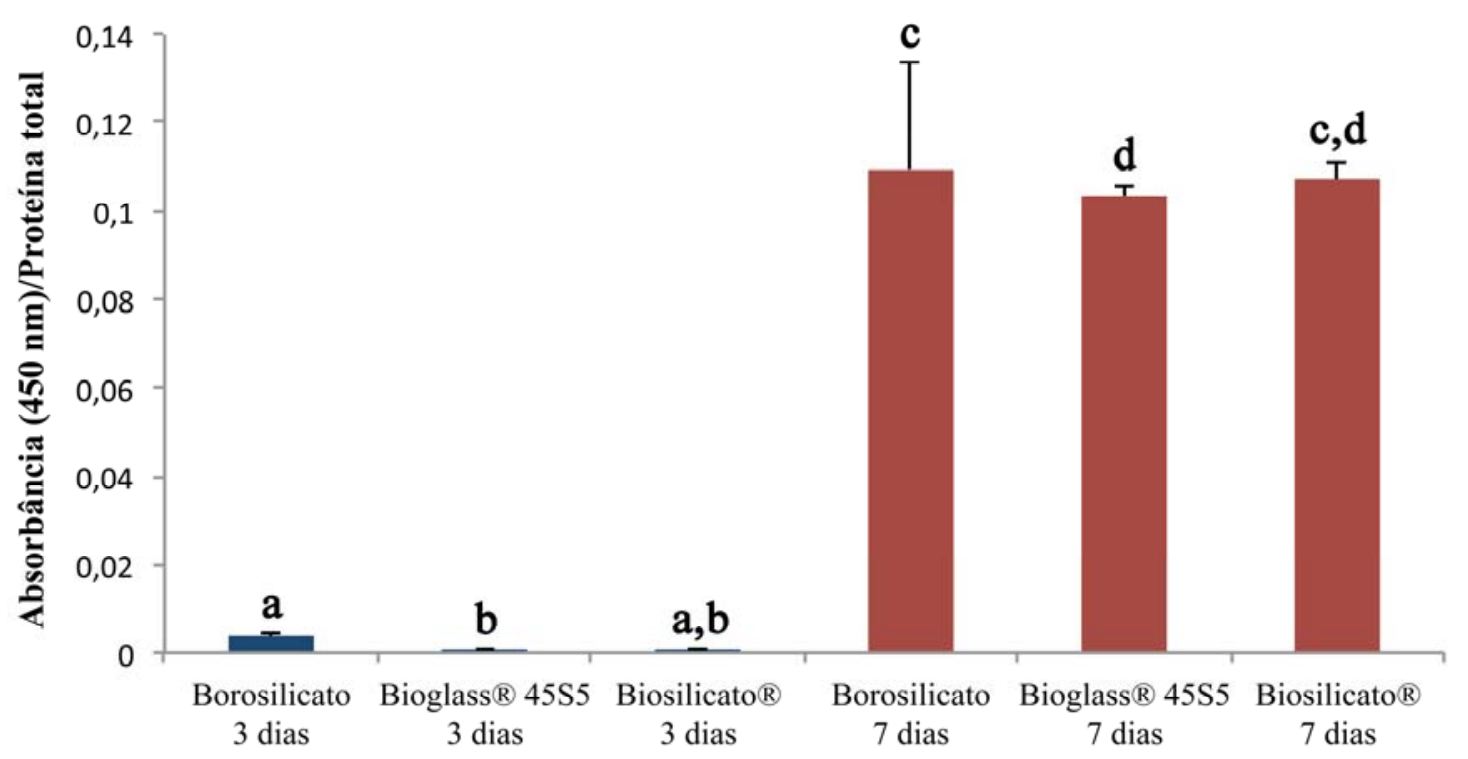

Figura 4. Quantificação de actina (média \pm desvio padrão) por ELISA de culturas de células osteogênicas crescidas sobre superfícies de borosilicato, Bioglass ${ }^{\circledR} 45 \mathrm{~S} 5$ e Biosilicato ${ }^{\circledR}$ aos 3 e 7 dias. Barras que compartilham uma letra não apresentam diferenças estatisticamente significantes $(p>0,05)$.

\section{Tubulina}

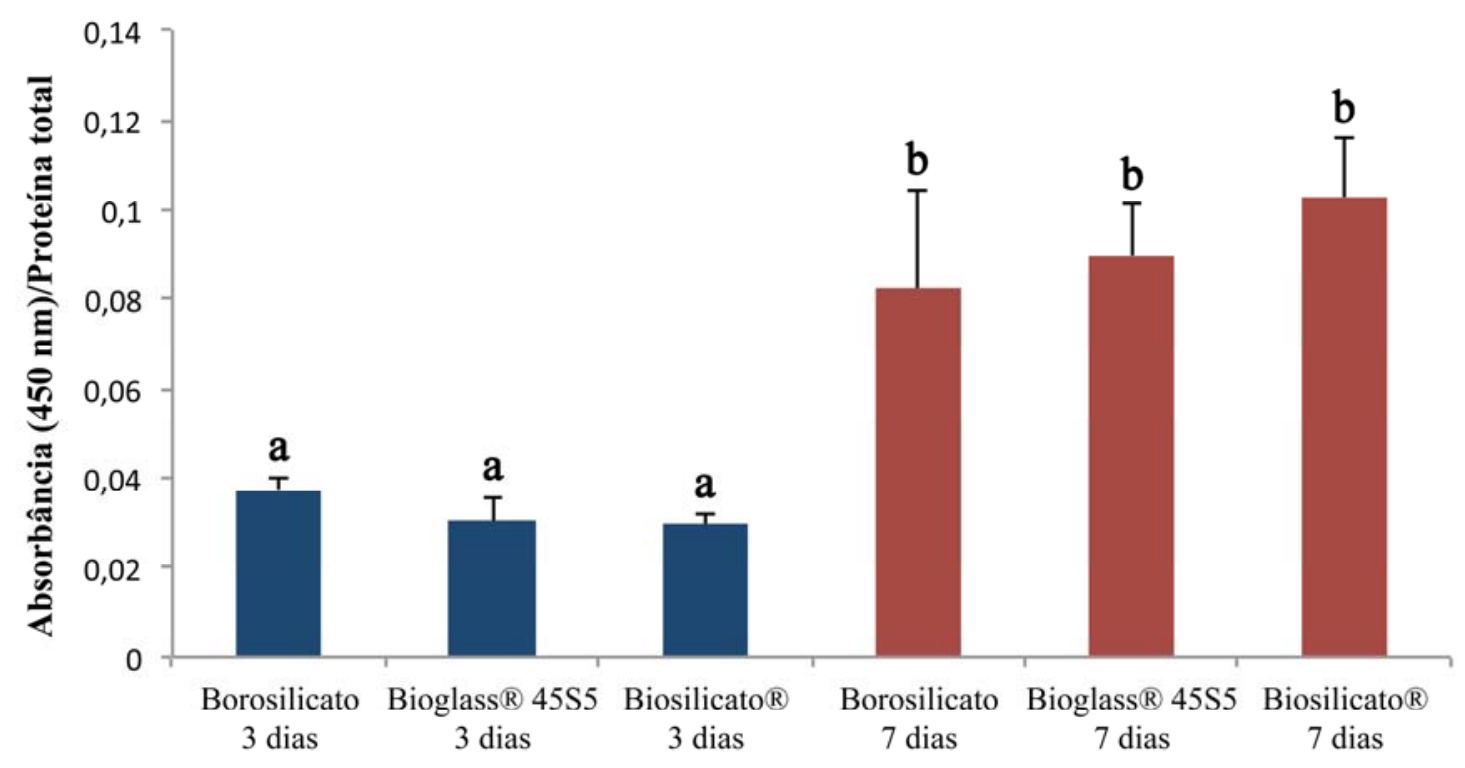

Figura 5. Quantificação de tubulina (média \pm desvio padrão) por ELISA de culturas de células osteogênicas crescidas sobre superfícies de borosilicato, Bioglass ${ }^{\circledR} 45 \mathrm{~S} 5$ e Biosilicato ${ }^{\circledR}$ aos 3 e 7 dias. Barras que compartilham uma letra não apresentam diferenças estatisticamente significantes $(p>0,05)$. 


\subsection{Correlação entre a expressão de RNAm e de proteína}

Frente a estes resultados, optamos por avaliar se haveria correlação positiva entre os valores de RNAm e de proteína, independentemente do material sobre o qual as culturas cresciam. O resultado do teste de Pearson mostrou não haver correlação entre expressão de RNAm e de proteína ( $p=0,18$ para actina e $p=0,32$ para tubulina; Figuras 6 e 7 ). No entanto, quando se avaliavam os pares de dados referentes a cada grupo individualmente, correlação positiva era observada apenas para culturas crescidas sobre o borosilicato (notem-se retas vermelhas nas figuras 6 e 7; respectivamente para actina e tubulina). Os valores de $p$ obtidos para actina foram: borosilicato, $p=0,002$; Bioglass $^{\circledR} 45 \mathrm{~S} 5, p=0,003$; Biosilicato $^{\circledR}, p=0,003$; e para tubulina: borosilicato, $p=0,01$; Bioglass ${ }^{\circledR} 45 \mathrm{~S} 5, p=0,01$; Biosilicato $^{\circledR}, p=0,28$. Com exceção para borosilicato, valores de $p<0,05$ indicam correlação negativa, enquanto que $p>$ 0,05 revela não correlação (nula).

\section{Correlação RNAm X Proteína - Actina}

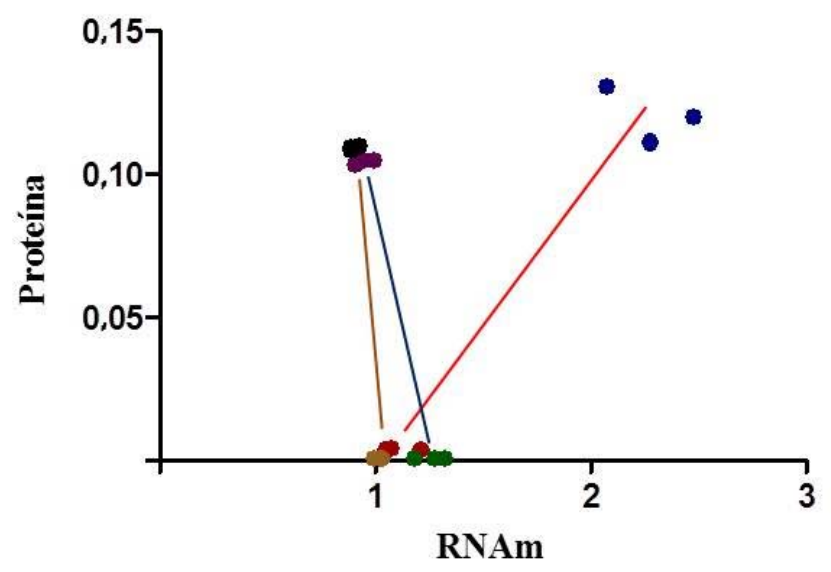

Borosilicato 3 dias Bioglass ${ }^{\circledR 4}$ 45S53 dias Biosilicato 3 dias Borosilicato 7 dias Bioglass $^{\circledR}$ 45S5 7 dias Biosilicato 7 dias

- Borosilicato

- Bioglass ${ }^{\circledR} 45 \mathrm{~S} 5$

- Biosilicato ${ }^{2}$

Figura 6. Teste de correlação de Pearson para os parâmetros de RNAm e proteína referentes à expressão de actina em culturas de células osteogênicas crescidas sobre superfícies de borosilicato, Bioglass ${ }^{\circledR} 45 \mathrm{~S} 5$ e Biosilicato $^{\circledR}$ aos 3 e 7 dias. Com todos os pares de dados, a correlação é nula $(p=0,18)$, enquanto que, individualmente, é positiva apenas para borosilicato $(p=0,002)$. 


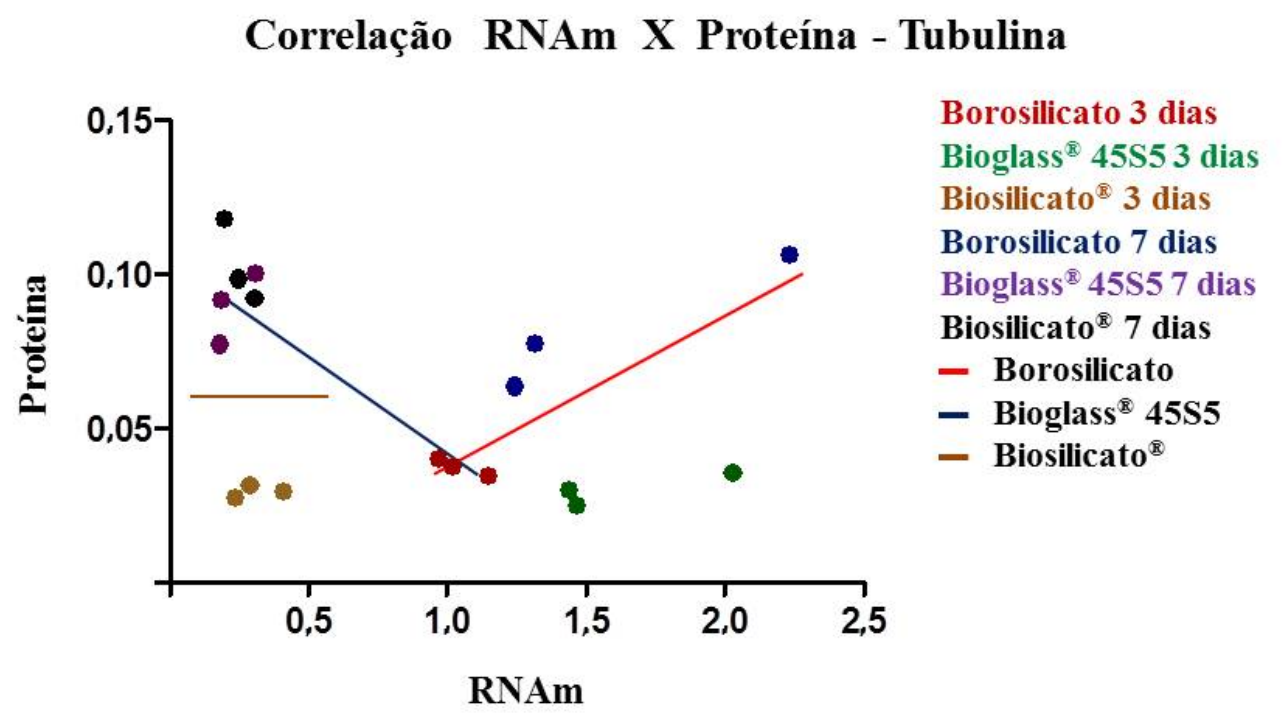

Figura 7. Teste de correlação de Pearson para os parâmetros de RNAm e proteína referentes à expressão de tubulina em culturas de células osteogênicas crescidas sobre superfícies de borosilicato, Bioglass ${ }^{\circledR} 45 \mathrm{~S} 5$ e Biosilicato $^{\circledR}$ aos 3 e 7 dias. Com todos os pares de dados, a correlação é nula $(p=0,32)$, enquanto que, individualmente, é positiva apenas para borosilicato $(p=0,01)$.

\subsection{Análise da morfologia celular por microscopia eletrônica de varredura (MEV)}

No período de 3 dias, as imagens obtidas mostraram que as células estavam aderidas e espraiadas sobre os 3 materiais, com maior espraiamento notado para aquelas sobre o borosilicato. Em relação às características da superfície dos materiais, Bioglass ${ }^{\circledR} 45 \mathrm{~S} 5$ e Biosilicato $^{\circledR}$ exibiam fendas típicas da presença de camada de sílica-gel e topografia na microescala compatível com a formação de fosfato de cálcio amorfo. Para esses grupos, as células mostravam-se parcial ou totalmente recobertas por material semelhante aos aspectos topográficos do substrato, mais aparente para Biosilicato ${ }^{\circledR}$, e que, por vezes, impedia a visualização nítida dos limites celulares (Figura 8). 


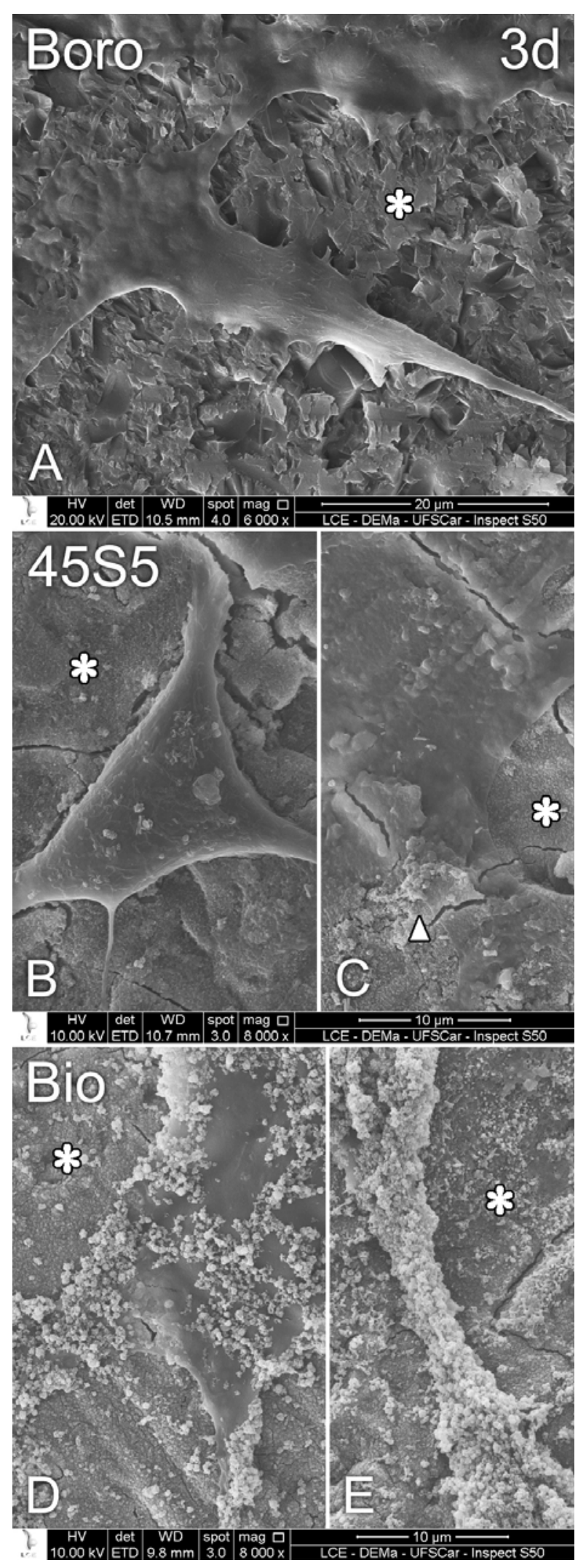

Figura 8. Microscopia eletrônica de varredura de células osteogênicas aderidas e espraiadas sobre superfícies de borosilicato (Boro; A), Bioglass ${ }^{\circledR} 45 \mathrm{~S} 5$ (45S5; B, C) e Biosilicato ${ }^{\circledR}(B i o ; D$, E) em 3 dias. (B-E) Para os materiais bioativos, observam-se, sobre as células, acúmulos de material de aspecto semelhante ao da topografia do substrato, por vezes impedindo a visualização dos limites celulares $(\mathrm{C}$, cabeça de seta) e podendo recobrir toda a superfície celular (E). Asteriscos indicam o substrato. 


\section{DISCUSSÃO}

Os resultados deste estudo in vitro mostraram que culturas de células osteogênicas crescidas sobre as superfícies bioativas de Bioglass ${ }^{\circledR} 45 \mathrm{~S} 5$ e Biosilicato ${ }^{\circledR}$ apresentam alterações da expressão de RNAm para actina e tubulina, embora isso não se reflita em variações significativas na quantidade das respectivas proteínas. Correlação positiva entre RNAm e proteína e correspondência entre as observações por epifluorescência e os dados quantitativos foram notadas apenas para culturas crescidas sobre a superfície bioinerte de borosilicato.

Durante o processo de interação de células com biomateriais, a expressão de proteínas citoesqueléticas está diretamente ligada aos fenômenos celulares de adesão, espraiamento, migração, proliferação, sinalização via transdução de sinais, expressão gênica e síntese e secreção de proteínas (ANSELME, 2000; BIGGS et al., 2009; BETTINGER; LANGER; BORENSTEIN, 2009; YIM et al., 2010; PENNISI et al., 2011). No presente estudo, optamos por avaliar duas das mais importantes proteínas do citoesqueleto, actina e tubulina, em células osteogênicas cultivadas sobre superfícies de Bioglass ${ }^{\circledR} 45 \mathrm{~S} 5$ e Biosilicato ${ }^{\circledR}$, respectivamente um vidro e uma vitrocerâmica altamente bioativos (HENCH et al., 1971; MOURA et al., 2007), em comparação com células crescidas sobre borosilicato. Conceitos clássicos de bioatividade que se aplicam a esses materiais estão relacionados à sua capacidade de se ligar à matriz óssea e de formar uma camada de HCA sobre sílica-gel quando expostos, em condições controladas in vitro, a fluido corporal simulado (SBF, na sigla em inglês); quanto maior a bioatividade do material, mais rápida a velocidade das reações de superfície que resultam na formação da camada de HCA (HENCH; WILSON, 1984). Essas reações, por promoverem modificações sequenciais na micro e nanotopografia do vidro e da vitrocerâmica avaliados, assim como em sua química/energia de superfície, e por liberarem produtos de 
dissolução iônica para o meio extracelular (DUCHEYNE; QIU, 1999; XYNOS et al., 2000; HENCH; POLAK, 2002), poderiam ter efeitos sobre os elementos citoesqueléticos das células osteogênicas, tanto em relação à expressão de RNAm, como à de proteína, ou mesmo na organização/direção dos feixes de filamentos citoplasmáticos. Nas condições de cultivo celular de nosso estudo, com modificações topográficas e de química de superfície já descritas anteriormente (MOURA et al., 2007; DE CASTRO, 2009), o impacto maior foi para alterações na expressão de RNAm para actina e tubulina em 3 e 7 dias e, possivelmente, na organização dos filamentos dessas proteínas, a julgar pela tendência a um menor espraiamento das células sobre Bioglass ${ }^{\circledR} 45 \mathrm{~S} 5$ e Biosilicato ${ }^{\circledR}$ em 3 dias.

Um aspecto importante dos resultados apresentados foi a não correspondência entre as imagens de epifluorescência e os parâmetros quantitativos para as culturas crescidas sobre os materiais bioativos. Por esse motivo, e pelas características de translucidez dos materiais, optou-se por também avaliar as células por microscopia que possibilitasse visualizá-las em resolução superior à do microscópio de fluorescência e em sua relação com os aspectos topográficos das superfícies sobre as quais estavam aderidas e espraiadas. A observação por MEV de recobrimento parcial ou total de células com material que se assemelhava à topografia do substrato, cujos agregados de estruturas esféricas irregulares e fendas em diferentes direções indicavam a formação de fosfato de cálcio amorfo sobre sílica-gel (MOURA et al., 2007; CASTRO, 2009), permitiu supor que a não visualização, parcial ou total, de actina e tubulina por epifluorescência deveria ser atribuída, pelo menos em parte, à presença de uma barreira física impedindo a excitação dos fluoróforos correspondentes. Os resultados de MEV permitem-nos avançar na compreensão do fenômeno de interação de células osteogênicas com substratos vítreos e vitrocerâmicos bioativos e na interpretação de suas avaliações por epifluorescência, originalmente descritas por nosso grupo (MOURA et al., 2007). Por fim, na possibilidade de esses acúmulos serem internalizados por endocitose, como 
sugere a presença, predominantemente em células aos 7 dias, de estruturas esféricas bem definidas e destituídas de fluorescência para actina e tubulina, novos estudos serão necessários para comprovar a existência de partículas de sílica-gel e/ou fosfato de cálcio no interior de vesículas citoplasmáticas e para avaliar o potencial impacto desse fenômeno sobre viabilidade celular, perfil de expressão gênica e fenótipo celular.

Os resultados do teste de correlação entre RNAm e proteína para actina e tubulina de culturas sobre todos os materiais conjuntamente contribuem para o conceito de que a expressão gênica deva ser avaliada tanto em relação à expressão de RNAm como à de proteína e reforçam as observações de não haver necessariamente correlação positiva entre esses dois parâmetros para genes que codificam diferentes proteínas (LEE et al., 2003; DE OLIVEIRA et al., 2008; GUO et al., 2008). Por exemplo, níveis elevados de RNAm podem não refletir quantidade abundante de proteína e vice-versa, como são os resultados observados em 7 dias para as culturas sobre Bioglass ${ }^{\circledR} 45 \mathrm{~S} 5$ e Biosilicato ${ }^{\circledR}$. Com efeito, a literatura descreve aspectos técnicos e biológicos que poderiam explicar as diferenças quantitativas entre expressão de RNAm e proteína, destacando-se as complexas relações entre transcrição e tradução, com modificações pós-transcrição e no processo de tradução (discutido por GUO et al., 2008). Além desses aspectos, nossos dados mostram que se devem, idealmente, considerar as características do substrato na interpretação dos resultados de testes de correlação entre RNAm e proteína em modelos de cultura de células. 


\section{CONCLUSÃO}

Os resultados do presente estudo permitem concluir que:

1. os efeitos da progressão de culturas de células osteogênicas em superfícies bioativas de Bioglass ${ }^{\circledR} 45 \mathrm{~S} 5$ e Biosilicato ${ }^{\circledR}$ sobre a expressão de actina e tubulina são maiores para os respectivos RNAm, com apenas discretas variações na quantidade das proteínas correspondentes;

2. não há correspondência entre os aspectos por epifluorescência de marcações para actina e tubulina e as respectivas quantificações de RNAm e proteína em culturas de células osteogênicas sobre Bioglass ${ }^{\circledR} 45 \mathrm{~S} 5$ e Biosilicato ${ }^{\circledR}$;

3. as alterações nos padrões de marcação por fluorescência para actina e tubulina devem ser atribuídas, pelo menos em parte, a acúmulos de material sobre as células osteogênicas, possivelmente decorrentes das reações de superfície a que estão submetidos Bioglass ${ }^{\circledR} 45 \mathrm{~S} 5 \mathrm{e}$ Biosilicato ${ }^{\circledR}$ quando em contato com o meio de cultura;

4. correlação entre RNAm e proteína para actina e tubulina em células osteogênicas pode ocorrer na dependência do material sobre o qual as culturas progridem, sendo positiva apenas sobre a superfície bioinerte de borosilicato, e negativa ou nula sobre as superfícies bioativas de Bioglass ${ }^{\circledR} 45 \mathrm{~S} 5$ e Biosilicato ${ }^{\circledR}$. 


\section{REFERÊNCIAS BIBLIOGRÁFICAS}

ANSELME, K. Osteoblast adhesion on biomaterials. Biomaterials, v.21, n.7, p.667-681, Apr. 2000.

BELlOWS, C.G.; AUBIN, J.E.; HEERSCHE, J.N.; ANTOSZ, M.E. Mineralized bone nodules formed in vitro from enzymatically released rat calvaria cell populations. Calcif Tissue Int, v.38, n.3, p.143-154, Mar. 1986.

BETTINGER, C.J.; LANGER, R.; BORENSTEIN, J.T. Engineering substrate topography at the micro- and nanoscale to control cell function. Angew Chem Int Ed Engl, v.48, n.30, p.5406-5415, 2009.

BIGGS, M.J.; RICHARDS, R.G.; GADEGAARD, N.; MCMURRAY, R.J.; AFFROSSMAN, S.; WILKINSON, C.D.; OREFFO, R.O.; DALBY, M.J. Interactions with nanoscale topography: adhesion quantification and signal transduction in cells of osteogenic and multipotent lineage. J Biomed Mater Res A, v.91, n.1, p.195-208, Oct. 2009.

BRUNSKI, J.B.; PULEO, D.A.; NANCI, A. Biomaterials and biomechanics of oral and maxillofacial implants:current status and future developments. Int J Oral Maxillofac Implants, v.15, n.1, p.15-46, Jan-Feb. 2000.

CHEN, C.S.; ALONSO, J.L.; OSTUNI, E.; WHITESIDES, G.M.; INGBER, D.E. Cell shape provides global control of focal adhesion assembly. Biochem Biophys Res Commun, v.307, p.355-361, 2003.

CHEN, Q.Z.; EFTHYMIOU, A.; SALIH, V.; BOCCACCINI, A.R. Bioglass ${ }^{\circledR}$-derived glassceramic scaffolds: Study of cell proliferation and scold degradation in vitro. J Biomed Mater Res A, v.84, n.4, p.1049-1060, Mar. 2008.

CHEN, Q.Z.; THOMPSON, I.D.; BOCCACCINI, A.R. 45S5 Bioglass-derived glass-ceramic scaffolds for bonetissue engineering. Biomaterials, v.27, n.11, p.2414-2425, Apr. 2006.

DE CASTRO, L.M.S. Osteogênese in vitro sobre vitrocerâmica $100 \%$ cristalina e altamente bioativa (Biosilicato ${ }^{\circledR}$ ): efeitos do condicionamento de superfície e dos produtos de dissolução iônica. 2009. 98 p. Dissertação (Mestrado em Biologia Oral) - Faculdade de Odontologia de Ribeirão Preto da Universidade de São Paulo, Ribeirão Preto.

DE OLIVEIRA, P.T.; DE OLIVA, M.A.; MAXIMIANO, W.M.; SEBASTIÃO, K.E.; CRIPPA, G.E.; CIANCAGLINI, P.; BELOTI, M.M.; NANCI, A.; ROSA, A.L. Effects of a mixture of growth factors and proteins on the development of the osteogenic phenotype 
in human alveolar bone cell cultures. J Histochem Cytochem, v.56, n.7, p.629-638, July 2008.

DE OLIVEIRA, P.T.; ZALZAL, S.F.; BELOTI, M.M.; ROSA, A.L.; NANCI, A. Enhancement of in vitro osteogenesis on titanium by chemically produced nanotopography. J Biomed Mater Res A, v.80, n.3, p.554-564, Mar. 2007.

DE OLIVEIRA, P.T.; ZALZAL, S.F.; IRIE, K.; NANCI, A. Early expression of bone matrix proteins in osteogenic cell cultures. J Histochem Cytochem, v.51, n.5, p.633-641, May 2003.

DE OLIVEIRA, P.T.; NANCI, A. Nanotexturing of titanium-based surfaces upregulates expression of bone sialoprotein and osteopontin by cultured osteogenic cells. Biomaterials, v.25, n.3, p.403-413, Feb. 2004.

DIEUDONNE, S.C.; VAN DEN DOLDER, J.; DE RUIJTER, J.E.; PALDAN, H.; PELTOLA, T.; VAN'T HOF, M.A.; HAPPONEN, R.P.; JANSEN, J.A. Osteoblast differentiation of bone marrow stromal cells cultured on silica gel and sol-gel-derived titania. Biomaterials, v.23, n.14, p.3041-3051, July 2002.

DISCHER, D.E.; JANMEY, P.; WANG, Y.L. Tissue cells feel and respond to the stiffness of their substrate. Science, v.310, n.5751, p.1139-1143, Nov. 2005.

DUCHEYNE, P.; QIU, Q. Bioactive ceramics: the effect of surface reactivity on bone formation and bone cell function. Biomaterials, v.20, n.23-24, p.2287-2303, Dec. 1999.

EZZELL, R.M.; TONER, M.; HENDRICKS， K.; DUNN， J.C.; TOMPKINS， R.G.; YARMUSH, M.L. Effect of collagen gel configuration on the cytoskeleton in cultured rat hepatocytes. Exp Cell Res, v.208, n.2, p.442-452, Oct. 1993.

GUO, Y.; XIAO, P.; LEI, S.; DENG, F.; XIAO, G.G.; LIU, Y.; CHEN, X.; LI, L.; WU, S.; CHEN, Y.; JIANG, H.; TAN, L.; XIE, J.; ZHU, X.; LIANG, S.; DENG H. How is mRNA expression predictive for protein expression? A correlation study on human circulating monocytes. Acta Biochim Biophys Sin (Shanghai), v.40, n.5, p.426-436, May. 2008.

HATTAR, S.; ASSELIN, A.; GREENSPAN, D.; OBOEUF, M.; BERDAL, A.; SAUTIER, J.M. Potential of biomimetic surfaces to promote in vitro osteoblast-like cell differentiation. Biomaterials, v.26, n.8, p.839-848, Mar. 2005.

HENCH, L.L. Bioceramics: From concept to clinic. J Am Ceram Soc, v.74, n.7, p.14871510, July 1991.

HENCH, L.L.; GREENLEE, T.K.; ALLEN, W.E.; PIOTROWSKI, G. An Investigation of Bonding Mechanisms at the Interface of a Prosthetic Material. Annual rept, n.2, p.110, Aug. 1971. 
HENCH, L.L.; POLAK, J.M. Third-generation biomedical materials. Science, v.295, n.5557, p.1014-1017, Feb. 2002.

HENCH, L.L.; WILSON, J. Surface-active biomaterials. Science, v.9, n. 226, p.630-6, Nov. 1984.

KIESWETTER, K.; SCHWARTZ, Z.; DEAN, D.D.; BOYAN, B.D. The role of implant surface characteristics in the healing of bone. Crit Rev Oral Biol Med, v.7, n.4, p.329345, 1996.

LEE, P.S.; SHAW, L.B.; CHOE, L.H.; MEHRA, A.; HATZIMANIKATIS, V.; LEE, K.H. Insights into the relation between mrna and protein expression patterns: II. Experimental observations in Escherichia coli. Biotechnol Bioeng, v.84, n.7, p.834-841, Dec. 2003.

LEVY, S.; VAN DALEN, M.; AGONAFER, S.; SOBOYEJO W.O. Cell/surface interactions and adhesion on bioactive glass 45S5. J Mater Sci: Mater Med, v.18, n.1, p.89-102, Jan. 2007.

LOSSDORFER, S.; SCHWARTZ, Z.; LOHMANN, C.H.; GREENSPAN, D.C.; RANLY, D.M.; BOYAN, B.D. Osteoblast response to bioactive glasses in vitro correlates with inorganic phosphate content. Biomaterials, v.25, n.13, p.2547-2555, June 2004.

LOTY, C.; SAUTIER, J.M.; TAN, M.T.; OBOEUF, M.; JALLOT, E.; BOULEKBACHE, H.; GREENSPAN, D.; FOREST, N. Bioactive glass stimulates in vitro osteoblast differentiation and creates a favorable template for bone tissue formation. J Bone Miner Res, v.16, n.2, p. 231-239, Feb. 2001.

LOWRY, O.H.; ROSEBROUGH, N.J.; FARR, A.L.; RANDALL, R.J. Protein measurement with the Folin phenol reagent. J Biol Chem, v.193, n.1, p.265-275, Nov. 1951.

MAMMOTO, A.; INGBER, D.E. Cytoskeletal control of growth and cell fate switching. Curr Opin Cell Biol, v.21, n.6, p.864-870, Dec. 2009.

MENDONÇA, G.; MENDONÇA, D.B.; ARAGÃO, F.J.; COOPER, L.F. Advancing dental implant surface technology--from micron- to nanotopography. Biomaterials, v.29, n.28, p.3822-3835, Oct. 2008.

MOURA, J.; TEIXEIRA, L.N.; RAVAGNANI, C.; PEITL, O.; ZANOTTO, E.D.; BELOTI, M.M.; PANZERI, H.; ROSA, A.L.; DE OLIVEIRA, P.T. In vitro osteogenesis on a highly bioactive glass-ceramic (Biosilicate). J Biomed Mater Res A, v.82, n.3, p.545557, Sept. 2007.

NANCI, A.; ZALZAL, S.; GOTOH, Y.; MCKEE, M.D. Ultrastructural characterization and immunolocalization of osteopontin in rat calvarial osteoblast primary cultures. Microsc Res Tech, v.33, n.2, p.214-231, Feb. 1996. 
PENNISI, C.P.; DOLATSHAHI-PIROUZ, A.; FOSS, M.; CHEVALLIER, J.; FINK, T.; ZACHAR, V.; BESENBACHER, F.; YOSHIDA, K. Nanoscale topography reduces fibroblast growth, focal adhesion size and migration-related gene expression on platinum surfaces. Colloids Surf B Biointerfaces, v.85, n.2, p.189-197, July 2011.

PULEO, D.A.; NANCI, A. Understanding and controlling the bone-implant interface. Biomaterials, v.20, n.23-24, p.2311-2321, Dec. 1999.

SARAVANAPAVAM, P.; JONES, J.R.; PRYCE, R.S.; HENCH, L.L. Bioactivity of gelglass powders in the $\mathrm{CaOSiO}_{2}$ system: A comparison with ternary $\left(\mathrm{CaO}-\mathrm{P}_{2} \mathrm{O}_{5}-\mathrm{SiO}_{2}\right)$ and quaternary glasses $\left(\mathrm{SiO}_{2}-\mathrm{CaO}-\mathrm{P}_{2} \mathrm{O}_{5}-\mathrm{Na}_{2} \mathrm{O}\right)$. J Biomed Mater Res Part A, v.66, n.1, p.110-119, July 2003.

SCHWARTZ FO, H.O.; NOVAES, A.B. JR.; DE CASTRO, L.M.; ROSA, A.L.; DE OLIVEIRA, P.T. In vitro osteogenesis on a microstructured titanium surface with additional submicron-scale topography. Clin Oral Implants Res, v.18, n.3, p.333-344, June 2007.

VETRONE, F.; VARIOLA, F.; TAMBASCO DE OLIVEIRA, P.; ZALZAL, S.F.; YI, J.H.; SAM, J.; BOMBONATO-PRADO, K.F.; SARKISSIAN, A.; PEREPICHKA, D.F.; WUEST, J.D.; ROSEI, F.; NANCI, A. Nanoscale oxidative patterning of metallic surfaces to modulate cell activity and fate. Nano Lett, v.9, n.2, p.659-665, Feb. 2009.

XYNOS, I.D.; HUKKANEN, M.V.J.; BUTTERY, L.D.K.; HENCH, L.L.; POLAK, J.M. Bioglass ${ }^{\circledR} 45 \mathrm{~S} 5$ stimulates osteoblast turnover and enhances bone formation in vitro: Implications and applications for bone tissue engineering. Calcif Tissue Int, v.67, n.4, p321-329, Oct. 2000.

YIM, E.K.; DARLING, E.M.; KULANGARA, K.; GUILAK, F.; LEONG, K.W. Nanotopography-induced changes in focal adhesions, cytoskeletal organization, and mechanical properties of human mesenchymal stem cells. Biomaterials, v.31, n.6, p.1299-1306, Feb. 2010.

ZANOTTO, E.D.; RAVAGNANI, C.; PEITL, O.; PANZERI, H.; LARA, E.H. Process and compositions for preparing particulate, bioactive or resorbable biosilicates for use in the treatment of oral ailments, WO2004/074199, Int. C. C03C10/00, Fundação UFSCar; USP, 20 Feb. 2004. 